\title{
Inhibitor of differentiation 4 (Id4) is a potential tumor suppressor in
} prostate cancer

\author{
Jason PW Carey ${ }^{1}$, Ananthi J Asirvatham ${ }^{1}$, Oliver Galm², \\ Tandeih A Ghogomu ${ }^{1}$ and Jaideep Chaudhary*1
}

\author{
Address: ${ }^{1}$ Department of Biology, Center for Cancer Research and Therapeutics Development, Clark Atlanta University, Atlanta, GA 30314, USA \\ and ${ }^{2}$ Medizinische Klinik IV, Universitaetsklinikum Aachen, RWTH Aachen, Pauwelsstrasse 30, 52074 Aachen, Germany \\ Email: Jason PW Carey - j_carey84@msn.com; Ananthi J Asirvatham - ananthi.josephine@gmail.com; Oliver Galm - Oliver.Galm@post.rwth- \\ aachen.de; Tandeih A Ghogomu - atandeih@cau.edu; Jaideep Chaudhary* - jchaudhary@cau.edu \\ * Corresponding author
}

Published: 7 June 2009

BMC Cancer 2009, 9:173 doi:10.1186/1471-2407-9-173
Received: 31 July 2008

Accepted: 7 June 2009

This article is available from: http://www.biomedcentral.com//47/-2407/9/173

(C) 2009 Carey et al; licensee BioMed Central Ltd.

This is an Open Access article distributed under the terms of the Creative Commons Attribution License (http://creativecommons.org/licenses/by/2.0), which permits unrestricted use, distribution, and reproduction in any medium, provided the original work is properly cited.

\begin{abstract}
Background: Inhibitor of differentiation 4 (Id4), a member of the Id gene family is also a dominant negative regulator of basic helix loop helix (bHLH) transcription factors. Some of the functions of Id4 appear to be unique as compared to its other family members IdI, Id2 and Id3. Loss of Id4 gene expression in many cancers in association with promoter hypermethylation has led to the proposal that Id4 may act as a tumor suppressor. In this study we provide functional evidence that Id4 indeed acts as a tumor suppressor and is part of a cancer associated epigenetic re-programming.
\end{abstract}

Methods: Data mining was used to demonstrate Id4 expression in prostate cancer. Methylation specific polymerase chain reaction (MSP) analysis was performed to understand molecular mechanisms associated with Id4 expression in prostate cancer cell lines. The effect of ectopic Id4 expression in DUI 45 cells was determined by cell cycle analysis $(3 \mathrm{H}$ thymidine incorporation and FACS), expression of androgen receptor, $\mathrm{p} 53$ and cyclin dependent kinase inhibitors p27 and p2I by a combination of RT-PCR, real time-PCR, western blot and immuno-cytochemical analysis.

Results: Id4 expression was down-regulated in prostate cancer. Id4 expression was also downregulated in prostate cancer line DUI45 due to promoter hyper-methylation. Ectopic Id4 expression in DUI45 prostate cancer cell line led to increased apoptosis and decreased cell proliferation due in part by an S-phase arrest. In addition to S-phase arrest, ectopic Id4 expression in PC3 cells also resulted in prolonged G2/M phase. At the molecular level these changes were associated with increased androgen receptor (AR), p2I, p27 and p53 expression in DUI45 cells.

Conclusion: The results suggest that Id4 acts directly as a tumor suppressor by influencing a hierarchy of cellular processes at multiple levels that leads to a decreased cell proliferation and change in morphology that is possibly mediated through induction of previously silenced tumor suppressors. 


\section{Background}

The Id genes (Id1, Id2, Id3 and Id4) are part of the broader basic helix loop helix family. The basic helix-loop-helix (bHLH) proteins are DNA binding proteins that regulate tissue-specific transcription within multiple cell lineages [1]. Hetero- or homo-dimerization-dependent DNA binding activity of class A bHLH proteins are regulated to a large part by the class D HLH inhibitors of differentiation (Id) gene family [2]. The Id proteins lack the DNA binding basic domain but have intact HLH domain [2,3]. This domain configuration allows the Id family to dimerize with bHLH transcription factors, but the lack of the basic domain renders the Id-bHLH dimer transcriptionally inactive, as it fails to bind and regulate promoter activity of genes dependent on E-box (CANNTG) response element [4]

The four different isoforms of Ids (Id1, Id2, Id3 and Id4) have a highly conserved HLH domain but divergent $\mathrm{N}$ and C-terminal domains. This sequence divergence may account for protein-specific interactions possibly resulting in differential functions of Id proteins [5-7]. Although all Id proteins interact with E-proteins, but isoform specific bHLH and non-bHLH interactions are known to occur. For example, interaction of a) Id 2 directly with hypophosphorylated pRb protein family [8,9] and polycystins [10] b) Id 2 and Id 4 with OLIG (class A bHLH, [11]) c) Id 1 and calcium/calmodulin-dependent serine protein kinase (CASK) [12] and d) Id 1 and Id 3 with $v$-ets erythroblastosis virus E26 oncogene homolog (Ets) [13] and Paired box transcription factor (Pax) homeodomain containing proteins [14]. Consistent with gene specific interactions, the Id proteins also exhibit isoform specific functions such as modulation of breast cancer 1, early onset (BRCA1) promoter activity by Id $4[15,16]$, localization of Id 1 to the centrosomes [17] leading to accumulation of cells with abnormal centrosome number and induction of apoptosis by Id2 in myeloid precursors, osteosarcoma [18] and neuronal cells [19] by an HLH independent mechanism.

In general, Id proteins (Id1-3) promote cell proliferation [20-22]. Consequently, the expression of Id proteins is generally high in proliferating cells that is down-regulated as a prerequisite for exit from the cell cycle during differentiation [23]. Consistent with this observation, an increased expression of various Id isoforms has been detected in many cancers [24-32].

In comparison to Id1, Id 2 and Id3, the function of Id4 is less understood and often conflicting. Both tumor promoting and tumor suppressor roles of Id 4 have been reported in many cancers. Tumor suppressor roles of Id4, based on its loss of expression in association with promoter hypermethylation have been suggested in leukemia [33], breast [34,35], colorectal [36] and gastric cancers
[37]. The pro-tumor effect of Id4 is observed in bladder [38] and rat mammary gland carcinomas [39]. Id4 is also the only Id gene that is deregulated by a $\mathrm{t}(6 ; 14)(\mathrm{p} 22 ; \mathrm{q} 32)$ chromosomal translocation in a B-cell acute lymphoblastic leukemia [40] and B-cell precursor acute lymphoblastic leukemia (BCP-ALL) [41].

The expression of Id4 in prostate epithelial cells is particularly interesting. Id4 appears to be androgen regulated in normal prostate epithelial cells [42] and in the androgen sensitive prostate cancer cell line LNCaP [43]. Id4 expression is undetectable or weakly expressed in androgen independent DU145 cells whereas its expression is observed (low) in PC3 prostate cancer cell lines [43]. LNCaP prostate cancer cells are generally considered less tumorigenic and more differentiated as compared to highly tumorigenic DU145 and PC3 prostate cancer cells. These observations suggest that Id4 expression may be associated with the state of differentiation and tumorigenic potential of prostate epithelial cells. This hypothesis was examined in the present study by over-expressing Id4 in androgen receptor negative DU145 and PC3 prostate cancer cells. Our results, demonstrate that Id4 attenuates cell cycle by promoting an S-phase arrest and induces androgen receptor expression. Id4 expression is also significantly reduced in prostate cancer samples as determined through data mining.

\section{Methods}

\section{Cell Lines and Cell Culture}

Human prostate cancer cell lines DU145 and LNCaP were obtained from American Type Culture Collection (ATCC, Rockville, MD). The DU145 cells were cultured in F12BCS-A (Ham's F12 (Gibco, Carlsbad, CA) medium containing 10\% Bovine Calf Serum (Hyclone) with appropriate antibiotics (pen/strep, fungizone, and gentamycin). LNCaP cells were cultured in RPMI-10\% Fetal Calf Serum (FCS) and antibiotics. The normal human prostate epithelial cells (PrEC) were obtained from Cambrex (Baltimore, $\mathrm{MD}$ ) and were cultured in PrEGM (Cambrex, Baltimore, MD) for approximately 10-15 doublings. Cells were cultured at $37^{\circ} \mathrm{C}$ in a fully humidified atmosphere containing $5 \% \mathrm{CO}_{2}$.

\section{5'-Aza-2-Deoxycytidine (5-AZA-CdR) Treatment}

The DU145 cells were cultured in F12-BCS-A containing 4 $\mathrm{uM}$ of 5 -AZA-Cdr ( $4 \mathrm{uM}$ ). The media with freshly added 5-AZA-Cdr was changed every 24 hours for 96 hours before harvesting the cells for RNA. The gene expression was analyzed before and after 5-AZA-Cdr treatment on the reverse transcribed RNA using gene specific primers.

\section{Plasmids and transfections}

The full length human Id4 cloned into pCMV vector (pCMV-Id4) was a generous gift from Dr. Mark Israel. The 
pCMV-Id4 vector and pCMV vector alone was transfected in sub-confluent (60\%) DU145 and PC3 cells grown in six well plates using TransIT-prostate transfection reagent cocktail $(10 \mu \mathrm{l}$ TransIT-prostate reagent, $5 \mu$ l prostate boost reagent (Mirus Bio) and $2 \mu \mathrm{g}$ pCMV-Id4 DNA in $200 \mathrm{ul}$ of serum free media). The culture media was changed once after an overnight incubation with the cocktail. Forty-eight hours after transfection, the cells with incorporated pCMV-Id4 were selected by incubation in fresh media containing $350 \mu \mathrm{g} / \mathrm{ml} \mathrm{G418} \mathrm{(Invitrogen)} \mathrm{for}$ one week with media change every 2 days. Following this selection cycle, the transfected cells were passaged once in F12-BCS-A and then re-exposed to F12-BCS-A with $350 \mu \mathrm{g}$ of G418/ml for an additional week (second G418 selection). This approach ensured the survival of only transfected cells. Simultaneous experiments were also performed in which cells were transfected with no DNA (control, parental) or with pCMV DNA (transfection control). The G418 selection procedure described above resulted in no surviving DU145 parental cells. The cells were grown to confluence (80\%), trypsinized $(0.25 \% \mathrm{v} / \mathrm{v}$ trypsin and $0.03 \% \mathrm{w} / \mathrm{v}$ EDTA in calcium- and magnesiumfree phosphate buffered saline), counted, and plated at a $1: 2$ dilution in new $100-\mathrm{mm}$ plates.

\section{RNA preparation}

Total RNA was extracted using TRIzol (Invitrogen, Carlsbad, CA) as described previously [43]. The final RNA pellet was re-suspended in diethylpyrocarbonate (DEPC)treated $\mathrm{H}_{2} \mathrm{O}$ at a concentration of $1 \mathrm{mg} / \mathrm{ml}$ and stored at $80^{\circ} \mathrm{C}$ until analysis.

\section{Proliferation assay}

DU145 cells were cultured at sub-confluent densities (growth permissive, 40\%) in 24 well plates (40\% confluency) and serum starved for 48 hours. The cells were then treated with $10 \%$ BCS for $20 \mathrm{~h}$ followed by a $6 \mathrm{~h}$ incubation with $[3 \mathrm{H}]$ thymidine. Counts per min $(\mathrm{cpm})$ of $[3 \mathrm{H}]$ thymidine incorporated into DNA were determined and normalized to the total DNA per well. Total DNA content was determined by SYBR green fluorescent assay [44].

\section{Gene Expression}

RNA ( $2 \mu \mathrm{g}$ ) was reverse transcribed in a final volume of 25 $\mu \mathrm{l}$ as per standard protocols (RT-Mix: $20 \mathrm{U}$ RNAout (Invitrogen, Carlsbad, CA); $1.25 \mathrm{mM}$ each of dNTP's; $250 \mathrm{ng}$ oligo dT (Promega, Madison, WI), 10 mM dithiothreitol, and $200 \mathrm{U}$ MMLV reverse transcriptase (Invitrogen) in the MMLV first-strand synthesis buffer (Invitrogen)). The RNA was denatured for $10 \mathrm{~min}$ at $65^{\circ} \mathrm{C}$, and then cooled on ice before addition of RT mix and enzyme. The reverse transcriptase reaction was carried out at $42^{\circ} \mathrm{C}$ for $1 \mathrm{~h}$.

Each PCR reaction was performed with 250 pg reversetranscribed DNA using published protocols [43]. The pos- sible contamination of RNA with DNA was distinguished by performing the RT reaction without MMLV reverse transcriptase enzyme (-MMLV RT). The PCR-based amplification reactions were carried out in duplicate on each reverse-transcribed RNA sample using gene specific primer sequences as indicated in respective figure legends. Simultaneous PCR reactions were also carried out using primers designed to $\beta$-actin to monitor the qualitative and quantitative efficiency of the RT-PCR reactions. The identity of each of the corresponding PCR products was size and sequence/restriction digest confirmed.

\section{Real-Time PCR}

Reverse transcribed RNA from DU145, DU145-Id4 and DU145-pCMV cells were used for real time quantitative gene expression analysis based on the TaqMan chemistry. The validated probes for Id4, $\beta$-actin (control), E-cadherin (CDH1), p21 (CDKN1A) and p53 were obtained from Applied Biosystems. Amplification of target sequences was detected with ABI7900HT sequence detection system (Applied Biosystems, Foster City, CA) and analyzed with ABI prism software (Applied Biosystems). All PCR reactions were performed in a final volume of $50 \mu$ laccording to the manufacturer's instructions (Applied Biosystems). The cycle threshold $(\mathrm{Ct})$ was used to calculate relative amounts of target RNA.

\section{Immuno cytochemistry}

The cells lines were cultured ( $60 \%$ confluency) in 8 chamber slides (Lab-Tek) at $37^{\circ} \mathrm{C}$ as described above. After 2 days in culture, the media was removed and the adherent cells were washed once with PBS. The cells were then fixed in cold methanol (20C) for 1 hour and stored at -20C. The fixed adherent cells on slides were equilibrated at $4 \mathrm{C}$ before further processing. The slides were incubated in $3 \%$ Bovine Serum Albumin (BSA) in PBS for 1 hour at $4 \mathrm{C}$ in order to block non-specific sites. The slides were then incubated with anti-Androgen Receptor-antibody (1:10,000, PG21, Millipore) or anti-actin antibody (1:10,000, H-196, Santa Cruz) for 1 hour at 4C. After primary antibody reaction, the cells were washed 3 times in PBS for 5 minutes each and then incubated with Alexa Fluor 594 anti-rabbit IgG (1:10, Invitrogen) at 4C for 1 hour. The slides were then rinsed for $5 \times 5$ minutes in PBS, counter stained with DAPI (VWR), post fixed with $3.7 \%$ formalin in PBS for 15 minutes and mounted with Glycerol. Cells were examined using a Fluorescent Microscope (Zeiss) and images captured via AxiomCam/AxioVision ( $\mathrm{v}$ 4.4).

\section{Western Blot Analysis}

The prostate cancer cell lines were cultured on $150 \mathrm{~mm}$ plates in their respective media. Cells $\left(5 \times 10^{6}\right)$ were dissociated off the plate by adding ice cold PBS and scrap- 
ping with a cell scraper. Total cellular protein was prepared as described previously [43].

20 ug of total protein was separated by $4-20 \%$ SDS-polyacrylamide gel (BioRad) and subsequently blotted onto a nitrocellulose membrane (BioRad). The blotted nitrocellulose membrane was subjected to western blot analysis using protein specific antibodies (Id4: Aviva ARP32335_T100) as mentioned above. After washing with $1 \times$ PBS with $0.5 \%$ Tween 20 , the membranes were incubated with a secondary antibody against anti-rabbit IgG (Pierce Rockford, IL) and the signal was visualized using the Super Signal West Dura Extended Duration Substrate (Pierce).

\section{Flow Cytometric Analysis of Cell Cycle Progression and apoptosis}

The DU145 and PC3 cells were cultured in 24 well plates to a sub confluent density. After the culture the cells were collected by trypsinization and washed with phosphate buffered saline. The cells were then fixed with 70\% ethanol and stored at $-20^{\circ} \mathrm{C}$ overnight. The following day, cells were washed twice with ice cold phosphate buffered saline PBS/FCS (10\%) followed by a final wash in $1 \times$ PBS. The cells were then finally resuspended $1 \mathrm{ml}$ of PBS $(1 \times)$ containing $50 \mu \mathrm{g} / \mathrm{ml}$ RNase A, $0.1 \%$ TritonX-100 and 1 $\mathrm{mM}$ EDTA and then incubated at $37^{\circ} \mathrm{C}$ for 30 minutes. Finally, $20 \mu \mathrm{g} / \mathrm{ml}$ of propidium iodide was added. Data acquisition and analysis were performed on a BD FACScan flow cytometer (Dept. of Biology, Spellman College, Atlanta, GA). The cell cycle profiles were then analyzed using BD Cellquest Pro (for apoptosis, Sub G0) and MODFIT software cell cycle analysis. At least 10,000 cells in each sample were analyzed to obtain a measurable signal. All measurements were performed using the same instrument settings.

The fraction of cells in Sub G0 phase was used to detect apoptotic cells. An increase in Sub G0 cells is due to loss of fragmented DNA as a result of apoptosis from permeabilised cells (ethanol fixed) due to DNA fragmentation. The cells stained with a DNA intercalating dye like propidium iodide, results in a DNA profile representing cells in G1, S-phase and G2M phase while the apoptotic cells are represented by a sub G0/G1 population seen to the left of the G0/G1 peak [45-47].

\section{Statistical analysis}

The $\Delta \Delta$ Ct method (Applied Biosystems User Bulletin2; ABI PRISM 7700 detection system) was used for relative quantification of gene expression. The $\mathrm{Ct}$ values of the target genes from triplicate PCR reactions were normalized to the levels of $\beta$-actin (endogenous control) from the same cDNA preparations. The average $\mathrm{Ct}$ for each gene was calculated by subtracting the Ct of the sample RNA from that of the control RNA. This value or $\Delta \mathrm{Ct}$ reflected the relative expression of the treated sample compared with the control and became the exponent in the calculation for amplification $2 \Delta$ Ctcont- $\Delta$ Ctsample, the equivalent to the fold change in expression. A statistically significant difference between various treatments and/or cell lines was determined by student's t-test.

\section{DNA Methylation Analysis}

The methylation status of the Id4 promoter region was analyzed using methylation-specific PCR (MSP) [48]. This assay entails the initial modification of genomic DNA by sodium bisulfite, converting all un-methylated cytosines to uracils, but leaving the methylated cytosines unchanged. Subsequently, the DNA region of interest was amplified in two separate reactions with primer pairs specific for either the methylated or the un-methylated sequence.

Genomic DNA was isolated using DNeasy kit (Qiagen). Approximately $1 \mu \mathrm{g}$ of DNA was sodium bisulfite-modified and subjected to MSP as described previously [48]. MSP primers that specifically recognized un-methylated Id4 sequence were 5'-GGT AGT TGG ATT TTT TGT TTT TTA GTA TT-3' (sense) and 5'-AAC TAT ATT TAT AAA ACC ATA CAC CCC A-3' (antisense); primers specific for the methylated Id4 sequence were 5'-TAG TCG GAT TTT TCG TTT TTT AGT ATC-3' (sense) and 5'-CTA TAT TTA TAA AAC CGT ACG CCC CG-3' (antisense). The primers for the $U$ reaction cover the bases -194 until -166 and -60 until -33 , and the primers for the $M$ reaction cover the bases -192 until -166 and -60 until -35 (relative to the transcription start site). Reactions were hot-started at $95^{\circ} \mathrm{C}$ for $5 \mathrm{~min}$ and held at $80^{\circ} \mathrm{C}$ before addition of 0.625 $\mathrm{U}$ of Taq polymerase (Sigma, St. Louis, MO). Temperature conditions for PCR were as follows: 35 cycles of $95^{\circ} \mathrm{C}$ for $30 \mathrm{sec}, 58^{\circ} \mathrm{C}$ for $30 \mathrm{sec}$ and $72^{\circ} \mathrm{C}$ for $30 \mathrm{sec}$, followed by 1 cycle of $72^{\circ} \mathrm{C}$ for 5 min. Normal DNA from peripheral blood was treated in vitro with SssI methyltransferase (New England Biolabs, Beverly, MA) in order to generate a positive control for methylated alleles of Id4 [49]. PCR products were separated on $2.5 \%$ agarose gels and visualized by ethidium bromide staining.

\section{Results}

Id4 expression is down-regulated in prostate cancer

Data mining of published microarray databases was used to determine the relative expression levels of Id4 in clinically relevant cases of prostate cancer as compared to controls and benign prostate hyperplasia. The consolidated Oncomine database [50] was queried against Id4 and all prostate databases were analyzed. Data from four of these representative studies is shown in Fig. 1. Between these four independent and unrelated studies [51-54], a total of 125 prostate cancer (PC), 13 metastatic prostate cancer 


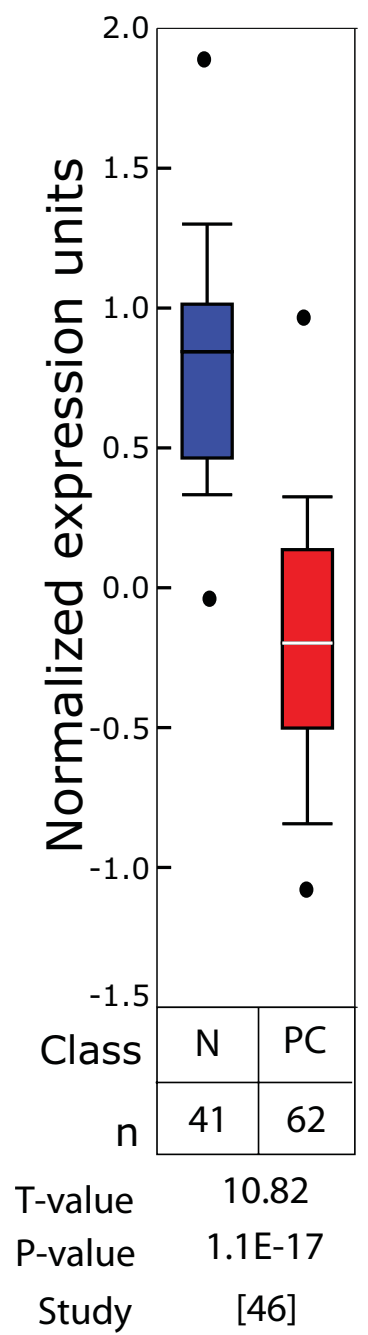

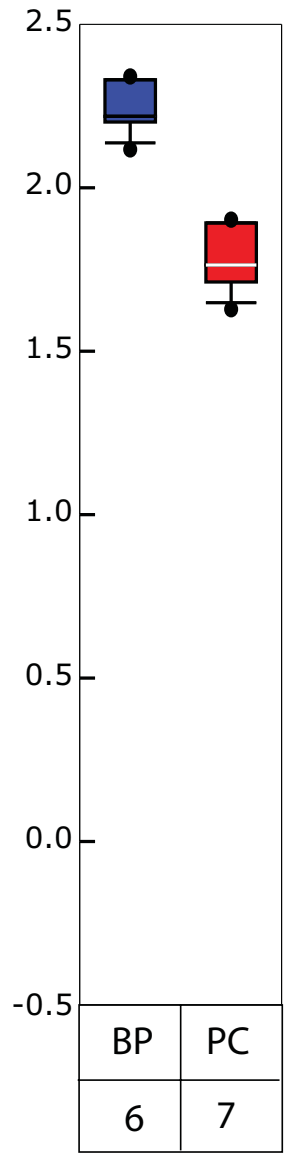

11.01

2.9E-7

[47]

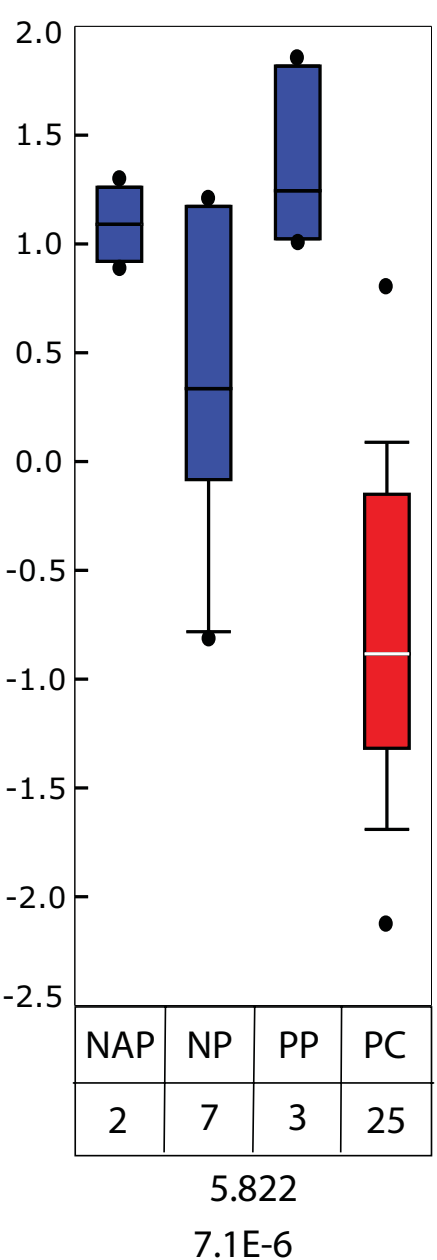

[48]

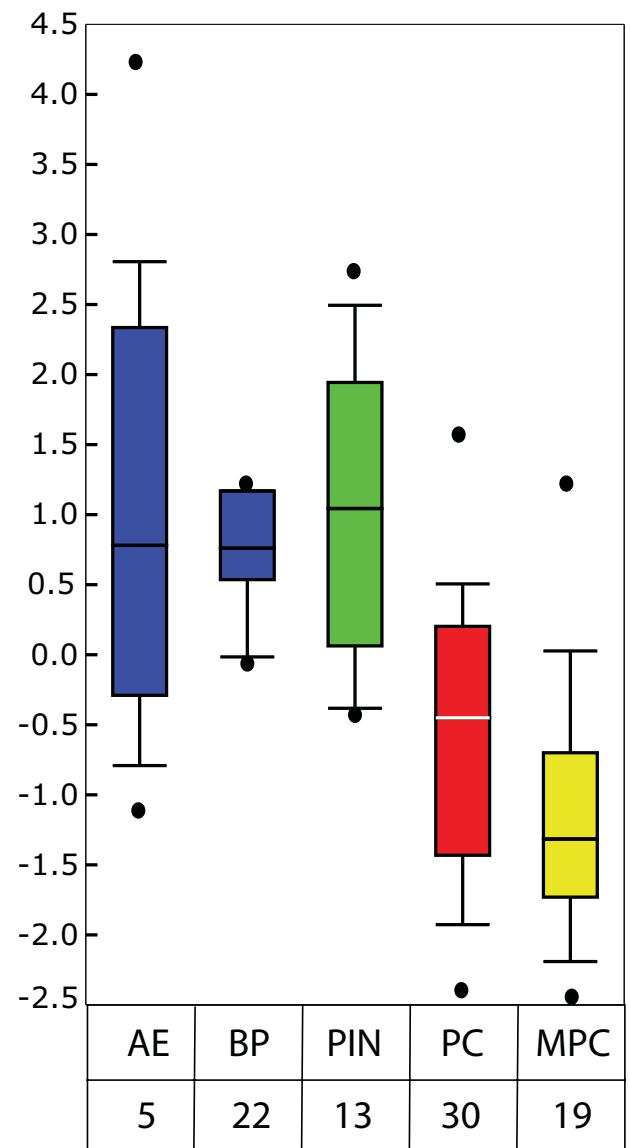

Correlation:-0.584

3E-7

[49]

Figure I

Id4 expression in prostate cancer as determined from publically deposited microarray databases. The Oncomine database was queried against Id4 and all prostate databases were analyzed. The box and whisker plots from four of these representative studies is shown [5I-54]. Consolidated data from all these studies demonstrated that Id4 is significantly (T-values $>$ 5 and low P-values < E-6) down-regulated in prostate cancer samples. Abbreviations: $n$ : No. of samples in each analysis, PC: Prostate Cancer (Red), MPC: Metastatic prostate cancer (Yellow), NAP: Normal adjacent prostate (Blue), NP: Normal Prostate (Blue), PP: Post-pubertal prostate (Blue), BP: Benign prostatic hyperplasia (Blue), PIN: prostate intra-epithelial neoplasia (green).

(MPC), 53 normal controls (41 Normal (N), 2 normal adjacent prostate (NAP), 7 normal adult prostate (NP), 3 post pubertal prostate (PP)), 28 benign prostate hyperplasia (BP) and 13 prostate intra-epithelial neoplasia (PIN) were analyzed. Normalized Id4 expression analysis in these samples indicated: 1) High Id4 in benign prostate hyperplasia as compared to prostate cancer suggesting that decreased Id4 is a cancer specific event 2) High normal adjacent (NAP) and post pubertal (PP) Id4 gene expression that may signify the role of Id4 in maintaining normal prostate function and 3) Low Id4 expression in prostate cancer (metastatic prostate cancer < prostate can- cer). Consolidated data from all these studies demonstrated that Id4 is significantly (T-values $>5$ and low Pvalues $<$ E-6) down-regulated in prostate cancer samples.

The molecular basis of Id 4 down-regulation and its significance in prostate cancer was studied in a well characterized prostate cancer cell line DU145. The DU145 prostate cancer cell line is negative or expresses very low Id4 and hence is an excellent model to study mechanisms involved in its down-regulation. In contrast, the normal human prostate epithelial cells (PrEC) and prostate cancer cell lines (LNCaP) [43] express Id4. 


\section{Id4 promoter methylation in DUI45 cells}

Results shown in Fig. 2A demonstrate that DU145 cells lack Id4 expression at the transcript and protein levels [43]. Lack of Id4 in DU145 cells is possibly due to its promoter hyper-methylation since treatment with global demethylation agent 5'-Aza-2-Deoxycytidine (5-AZA$\mathrm{CdR}$ ) resulted in the induction of Id4 gene and protein expression (Fig. 2A). The methylation at the CpG island located around the transcription start site leading to the epigenetic silencing of Id 4 in several human solid tumors $[33,34,36,37]$ have been reported. These results prompted us to investigate the methylation status of the Id4 promoter region in DU145 cells by MSP (Methylation Specific PCR). As shown in Fig. 2B, the Id4 promoter region in DU145 cells is also methylated as compared to Id4 expressing LNCaP cells, human fibroblasts and normal peripheral blood mononuclear cells. Thus, aberrant methylation of the promoter region appears to be associated with Id4 gene silencing in AR negative DU145 cells.

\section{Effect of Id4 on Cell Proliferation, Morphology and Apoptosis}

Two weeks post-transfection, the expression of Id4 in DU145 cells transfected with pCMV-Id4 was evaluated with real time PCR analysis. A more than 10 fold increase in Id4 expression in DU145-Id4 cell line as compared to the parental DU145 cells confirmed that Id4 was being expressed in the pCMV-Id4 transfected cells (after $1^{\text {st }}$ G418 selection). Similar levels of Id4 (range 7.5-11 fold) was also observed after 2nd G418 selection. The Id4 expression in CMV transfected cells was negligible and was comparable to that in parental DU145 cells. Following this analysis, the cells were allowed to grow for at least 15 passages before subjecting to cellular/molecular analysis.

A change in morphology in DU145-Id4 cell lines was observed (Fig. 3). A significant observation was the appearance of "epithelial like" morphology that was associated with increased cell-cell adhesion of DU145-Id4 cells as compared to a mesenchymal morphology of the parental DU145 cells (Fig. 3).

The slow but continuous rate of proliferation suggested that DU145-Id4 cells have not undergone senescence (at least until passage 28). In vitro growth curves (Doubling time, Fig. 4A) indicated a decrease in cell proliferation (increased doubling time) in DU145-Id4 cells as com-
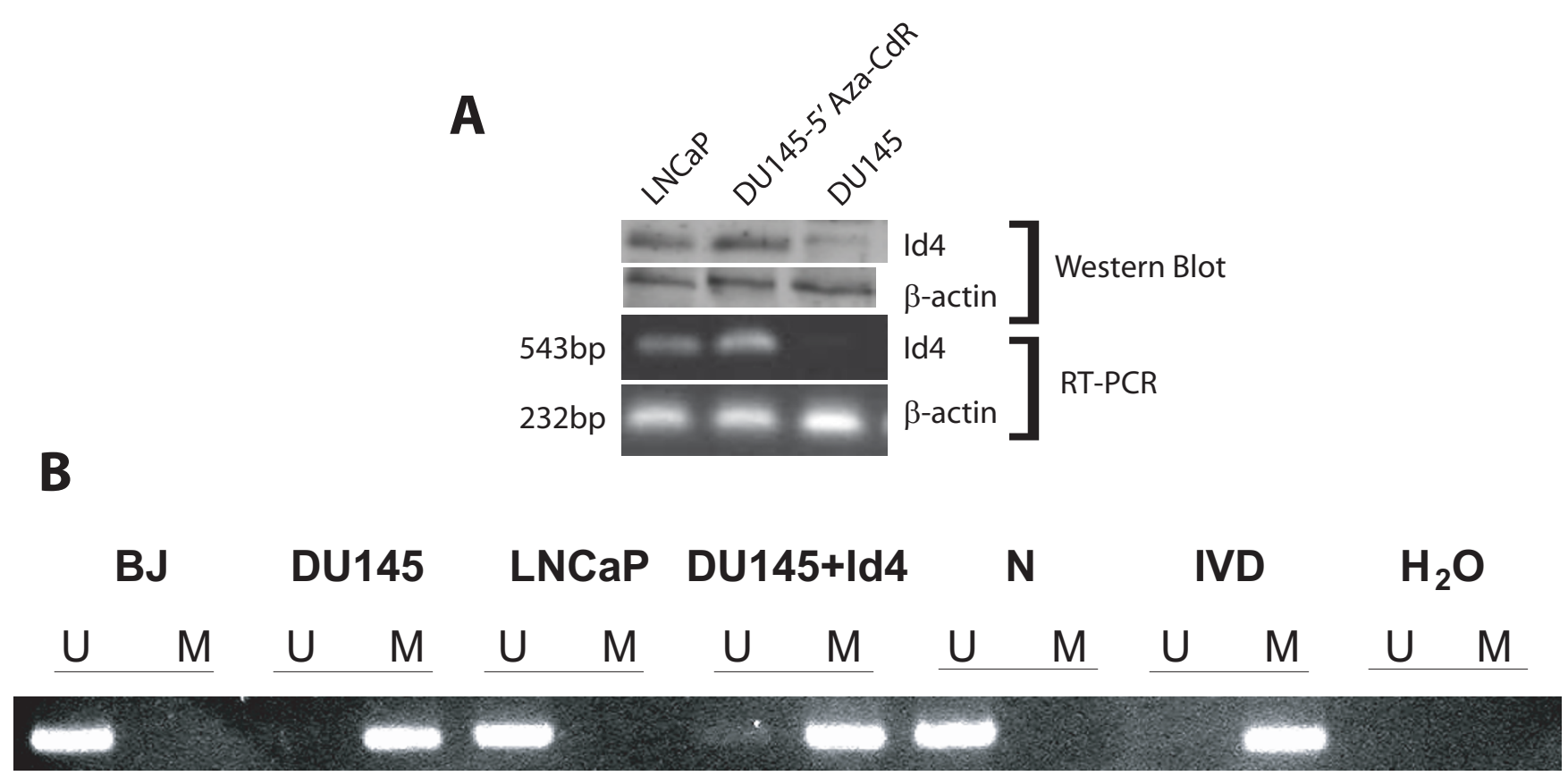

Figure 2

(A) Id4 expression is generally absent in DUI45 cells but present in androgen receptor positive LNCaP cells. Treatment of DUI45 cells with global de-methylation agent 5'-Aza-2-Deoxycytidine (5-AZA-CdR) leads to Id4 expression as determined by western blot analysis (upper panel) and reverse transcriptase polymerase chain reaction (RT-PCR, lower panel). Beta-actin was used as a loading and RT-PCR control. The primer pairs used for amplification were described in [43]. (B) Analysis of Id4 methylation in human fibroblasts (BJ) and the prostate cancer cell lines DUI45, DUI45-Id4 (DUI45 cells with constitutively expressed Id4) and LNCaP by methylation specific PCR (MSP). The presence of a PCR band in lanes marked "M" indicates a methylated gene sequence, the presence of a PCR band in lanes marked " $U$ " indicates an un-methylated gene sequence. Normal peripheral blood cells (N), in vitro methylated DNA (IVD) and water served as controls. 

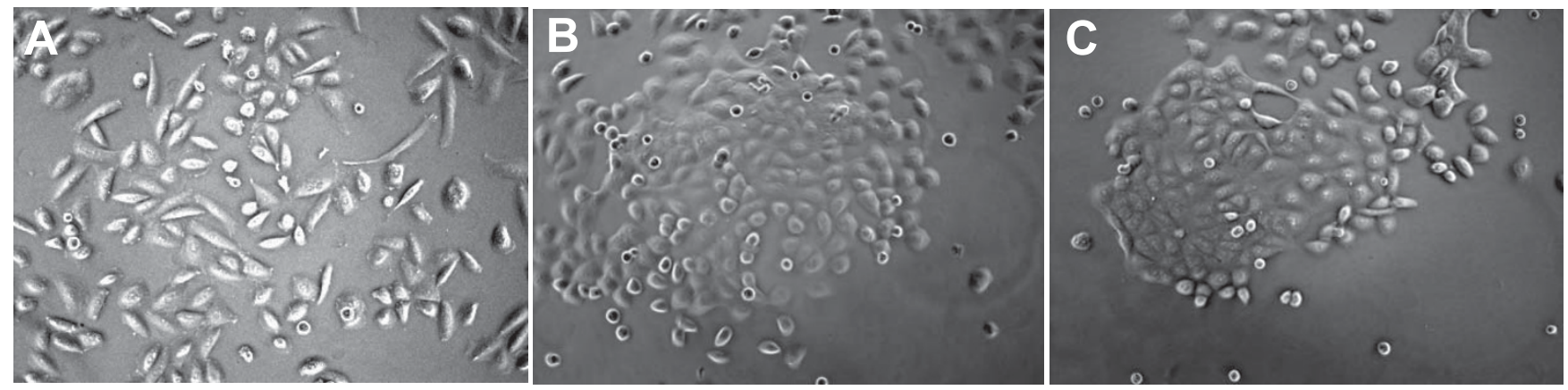

Figure 3

Morphology ( $\times 100)$ of the DUI45 and DUI45-Id4 cell lines in culture. (A) Parental DUI45 cells show a more mesenchymal morphology that is long and spindle shaped. (B \& C) The DUI45-Id4 cells appear more like epithelial cells that tend to adhere to each other hence appear as clusters. The DUI45-Id4 cell line shown above is at passage 28.

pared to non-transfected DU145 and DU145-pCMV (empty vector transfected) cells. The decreased proliferation of DU145-Id4 cells as compared to DU145 and DU145-CMV were also reflected in 3H-thymidine incorporation assay that measures DNA synthesis (Fig. 4A). Fluorescent Assisted Cell Sorting (FACS) was then used to understand the effect of Id4 on cell cycle. Two different approaches were used: The first approach was used to determine the fraction of cells in the Sub-G0 population as an estimate of apoptosis and the second approach, using ModFit software was used to determine the fraction of cells in each phase of the cell cycle. The DU145-Id4 cells demonstrated increased apoptosis as indicated by increased cell counts in sub-G0 phase as compared to DU145 cells (Fig. 4B).

The decreased proliferation of DU145-Id4 cells was due to lower number of cells in the G0/G1 and G2/M phase (Fig. 5B) as compared to DU145 cells (Fig. 5A). A significant observation was the increase in the number of cells in the S-phase in DU145-Id4 cells (Fig. 5B) as compared to DU145 cells (Fig. 5A). Collectively, these results demonstrated that Id4 expression induces a change in cell morphology/adhesion, decreased proliferation possibly to due to an S-phase arrest and increased apoptosis.

The effect of Id4 expression on PC3 was also investigated to confirm the results obtained from DU145 cells. PC3 cells are weakly positive for Id4 expression (Fig. 5C) but nevertheless provide a good model to investigate the effect of ectopic Id4 expression on prostate cancer cells (Fig. 5C). Although detailed analysis of PC3-Id4 cell line is ongoing but initial results on cell cycle profiling by FACS analysis demonstrated striking similarities to the DU145Id4 cells line. The PC3-Id4 cell line also demonstrated an S-phase arrest (Fig. 5E) as compared to PC3 cells (Fig. 5D). The cell cycle profile between PC3 cells and PC3 cells transfected with empty vector were similar (data not shown). The ratio of cells in S-phase (\% Cells in Id4 cell lines/\% cells in parental lines in each corresponding cell cycle phase) in DU145-Id4 and PC3-Id4 were strikingly similar (Fig. 5F). The data normalization also suggested that unlike DU145-Id4, the PC3-Id4 cell line may have an additional block at G2/M phase.

\section{Gene Expression Changes in DUI45-Id4 cell lines}

The likely candidates involved in suppressing proliferation are the cyclin dependent kinase inhibitors (CDKNI) p21 and p27. The expression of p21 and p27 in DU145Id4 cells was determined by semi-quantitative RT-PCR analysis (Fig. 6A and 6B). The expression of p21 in DU145-Id4 and normal prostate epithelial cells (PrEC) was significantly higher as compared to parental DU145 cells $(\mathrm{P}<0.05)$. The expression of p27 was also significantly higher in DU145-Id4 cells as compared to DU145 cells in which it expression was absent or below detection levels $(\mathrm{P}<0.001)$. A highly significant increase (over 15 fold, Real Time PCR) in p53 transcript level was observed in DU145-Id4 cell line as compared to DU145 cells (Fig. 6C). Thus, the decrease in DU145-Id4 cell proliferation appears to be mediated in part by increased expression of classical tumor suppressors' p27 and p21.

At the molecular level, the transition towards "epithelial type" morphology and increased cell adhesion of DU145Id 4 cells could be due an increase in E-cadherin expression as determined by real-time PCR analysis (Fig. 6C). The E-cadherin expression in DU145-Id4 cells was at least five fold higher than DU145 cells (Fig. 6C).

One of the hallmarks of the DU145 cell line, a representative of androgen depletion-independent cancers, is the loss of androgen receptor. Based on our observations that ectopic expression of Id4 can decrease proliferation, increase apoptosis and induce a transition towards an epithelial phenotype, we considered the possibility that Id4 
A
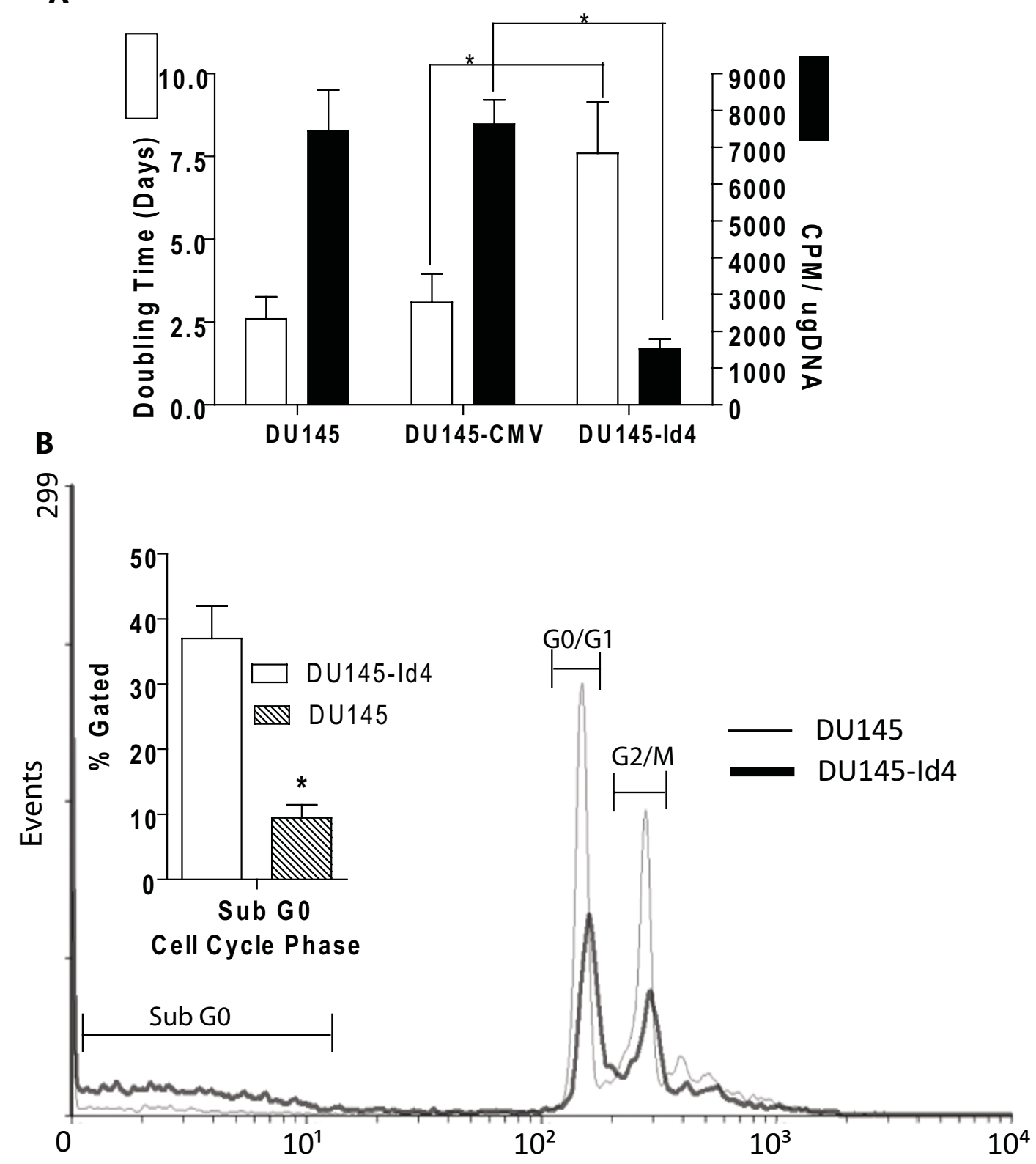

Figure 4

(A): Doubling time (in days, White bars) and rate of proliferation (Black bars) of DUI45, DUI45-CMV and DUI 45-Id4 cells line in culture. All the cell lines have matched passages. The DUI 45 cells were either transfected with no plasmid (DUI45), CMV vector alone (DUI45-CMV/EV) or PCMV-Id4 (DUI45-Id4). White Bars: The average doubling time of DUI45-Id4 cells as compared to DUI45 and DUI45-CMV. The data is an average cell count from four passages. The doubling time was calculated by counting days required for the number of plated cells (usually at $40 \%$ confluence) to reach confluence (80\%). For DUI45-Id4 cells, this average is from passage 13-16. A highly significant increase in the doubling time (approximately 2.5 fold $)(P<0.00 \mathrm{I})$ suggests that Id 4 over-expression leads to a decrease in proliferation. Black Bars: $3 \mathrm{H}$ thymidine incorporation assay. $3 \mathrm{H}$ thymidine incorporation (CPM) was evaluated as a measure of rate of proliferation. The counts per minute (CPM) of incorporated $3 \mathrm{H}$-thymidine was normalized to total DNA. The data represents CPM/ug DNA of cell lines at passages 14 and 15. The data is represented as mean \pm SEM of three experiments performed in triplicates. $*: P<0.00$ I. (B) FACS analysis of cell cycle parameters in DUI45 and DUI45-Id4 cell lines. The cell cycle profile showing fraction of cells in each phase of the cell cycle in DUI45-Id4 and DUI45 cells is shown. The data is representative of at least three experiments. The inset shows the fraction of cells in sub-G0 phase (normalized to 10,000 cells). The cells in sub-G0 phase have low DNA content possibly due to apoptosis. The mean \pm SEM of three experiments performed in triplicate is shown $(*: P<0.00 I)$. 

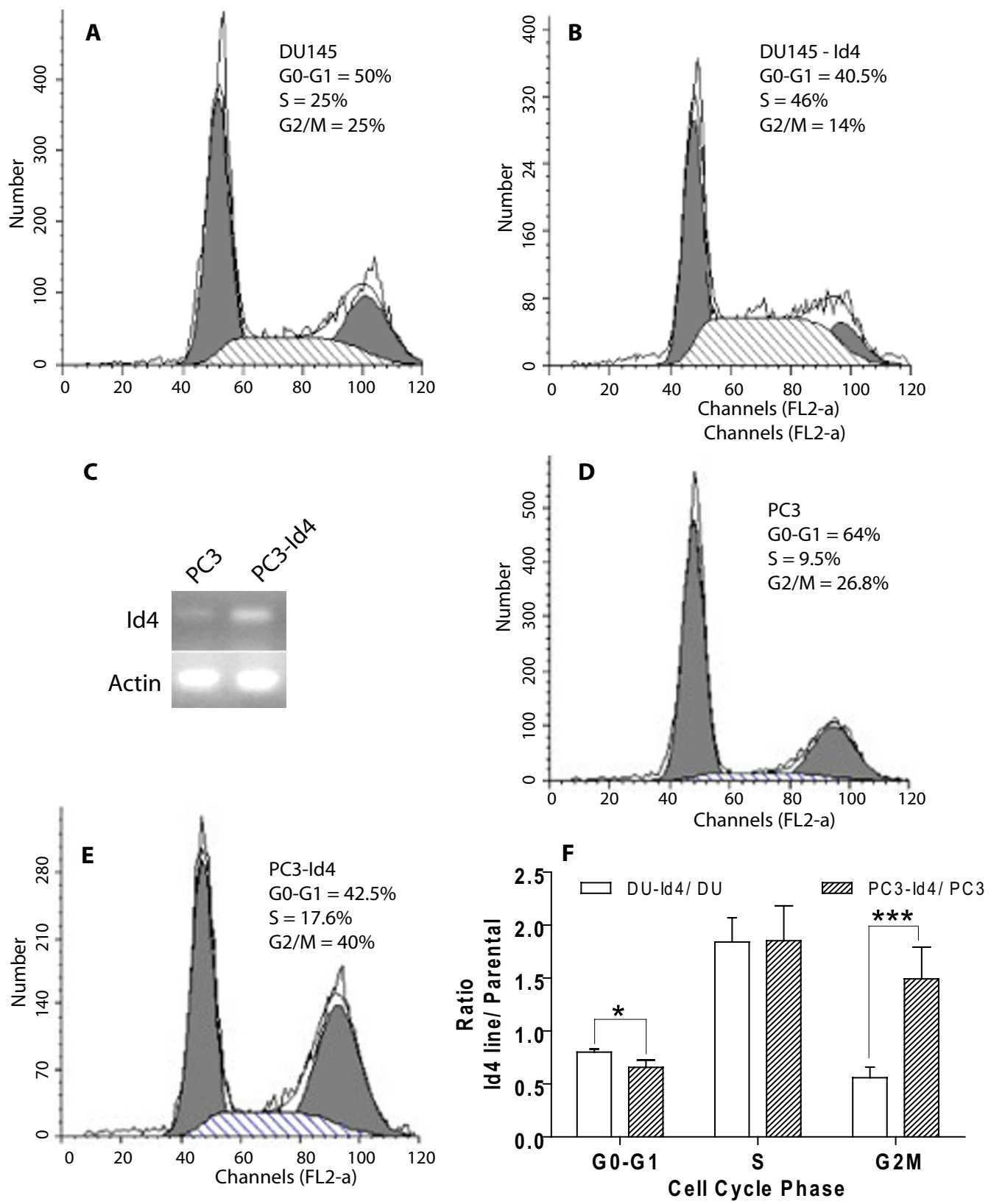

\section{Figure 5}

FACS analysis of cell cycle parameters in DUI45, DUI45-Id4, PC3 and PC3-Id4 cell lines. The cells were serum starved for 24 hours in order to synchronize the cell cycle. The cells were then serum stimulated (I0\% BCS) in order to determine the effect of Id4 on cell cycle. A and D: Serum treated DUI45 and PC3 cells respectively, B and E: Serum treated DUI45-Id4 and PC3-Id4 cells respectively. The cell cycle analysis and the fraction of cells in each phase (G0-GI, S and G2/M, indicated as \% cells) were determined using ModFit cell cycle analysis software. The data is representative of triplicate experiments. Of note is the number of cells (scale) represented on the $\mathrm{Y}$-axis. C: Reverse Transcriptase polymerase chain reaction demonstrating the expression of Id4 in PC3 (lane I) and PC3 cells stably transfected with Id4 expression plasmid (Lane 2). Weak Id4 expression was observed in PC3 cells whereas significantly higher expression was observed in PC3-Id4 cells (representative of 3 different PCR reactions). F: The ratio of cells in each phase. The ratio was calculated by dividing the \% cells in Id 4 expressing cells by parental cells in each phase of cell cycle. This calculation was used to normalize and compare the data between two cell lines. The error bars represent standard error of mean calculated from three different experiments (*: $\mathrm{P}>$ 0.05 and $* * *: \mathrm{P}>0.00 \mathrm{I})$. 


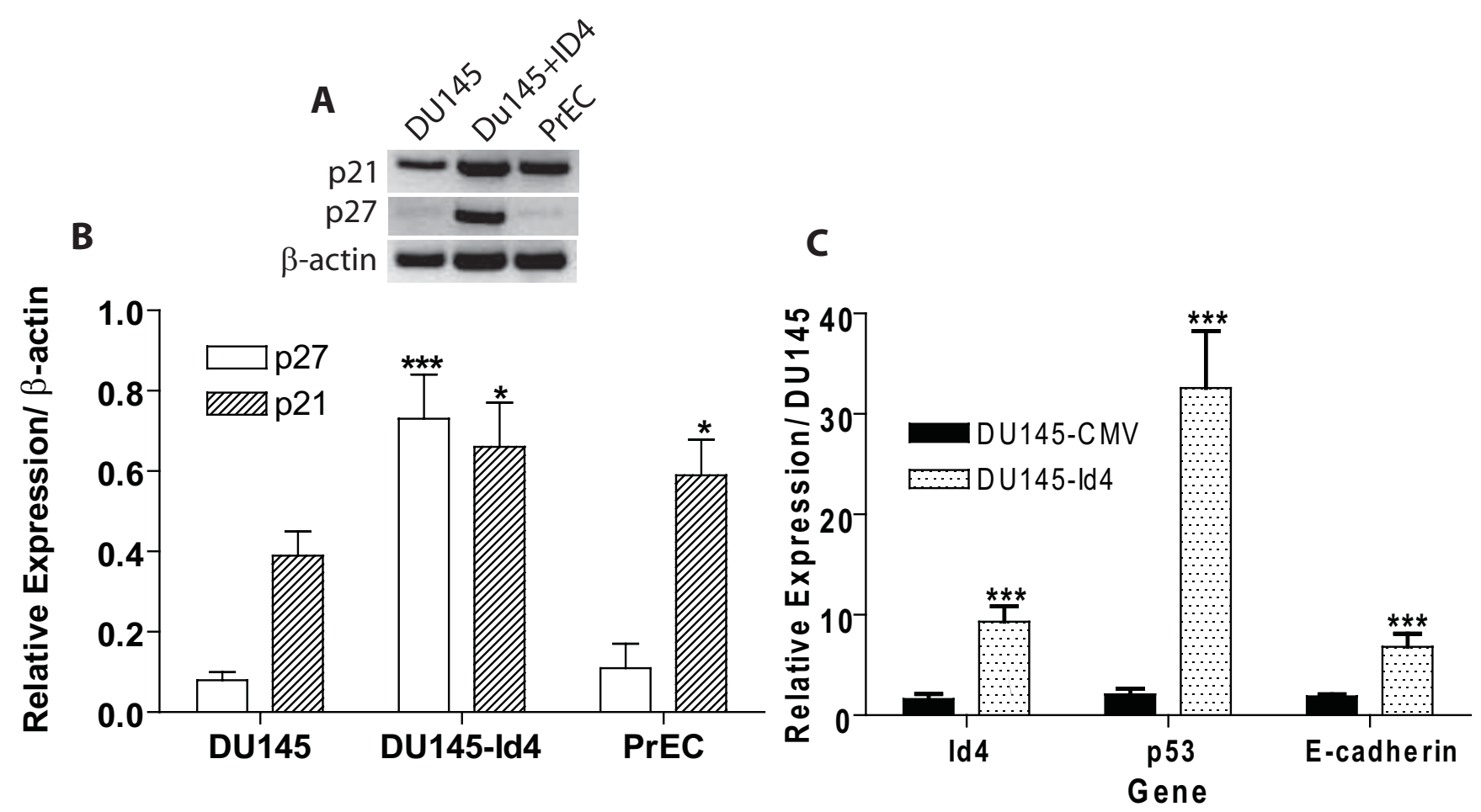

Figure 6

(A): RT-PCR and semi-quantitative expression levels of cyclin dependent kinase inhibitors p27 and p2I in DU I 45, DU I 45-Id4 and PrEC (normal prostate epithelial) cells. (B) Semi-quantitative analysis of RT-PCR results shown in (A). The intensity of each p27 and p2I band was normalized to constitutively expressed beta actin. The RT-PCR data and semi-quantitative analysis (expressed as mean \pm SEM) is representative of 3 different $R T$ and corresponding PCR reactions (***: $P<0.00 I$, *: $P<0.05$ as DUI 45). The following primers were used: 227 (CDKNIA): Forward 5'-TCA AAC GTG CGA GTG TCT AA and Reverse 5'-ACG TTT GAC GTC TTC TGA GG, p2 I: Forward 5'-CGA CTG TGA TGC GCT AAT G and Reverse 5'-TTA GGG CTT CCT CTT GGA GA, $\beta$-actin: Forward-5' AGA AAA TCT GGC ACC ACA CC, Reverse-5' GGG GTG TTG AAG GTC TCA AA. (C): Real time analysis of Id4, p53 and E-cadherin gene expression in DUI45, DUI45-CMV and DUI45-Id4 cell lines. The data performed in triplicate is mean \pm SEM from cells at passages I8, 20 and 23 . The real time data is normalized to the constitutively expressed gene beta-actin. The relative expression levels were calculated by the $\Delta \mathrm{Ct}$ method as described in materials and methods section. The RT-PCR data is representative of 3 different RT and corresponding PCR reactions (***: $\mathrm{P}<0.00 \mathrm{I}$, as compared to DUI45).

may re-induce AR expression. Indeed, Id4 over expression led to a highly significant increase in the expression of androgen receptor in DU145 cells as determined by western blot analysis (Fig. 7A, upper panel), RT-PCR (Fig. 7A, lower panel) and real time PCR (Fig. 7B). The androgen receptor expression in DU145-Id4 cells was further confirmed at the cellular level by immuno-cytochemistry (Fig. 8A). As expected, the AR expression in DU145-Id4 cells was localized primarily to the nucleus (Fig. 8A). A similar AR expression was also observed in AR +ve LNCaP cells (Fig 7A,B and Fig. 8E). Consistent with our RT-PCR and western blot analysis, AR expression was largely absent in parental DU145 cells (Fig 7A,B and Fig. 8C). Studies have demonstrated that DU145 cells are negative for androgen receptor due to promoter methylation [55] or express low levels of androgen receptor [56]. Therefore, induction of AR expression by Id 4 can be due to a number of pathways, most notably through demethylation of AR promoter and/or induction of alternate transcriptional pathways required for AR expression.

The Id family of bHLH proteins interacts with and negatively regulates the bHLH proteins that generally induce differentiation and block proliferation. Primary among bHLH-Id interaction partners are the tumor suppressor E2A proteins E12/E47 [57]. At the transcriptional level, Id proteins also down regulate E2A $[58,59]$. Unexpectedly, Id4 expression was associated with increased expression of E12/E47 transcript (Fig. 7A). The induction of E12/E47 by Id 4 therefore seems to be an isoform specific function $[58,59]$. Thus, one of the mechanism by which Id 4 may exert its tumor suppressive effect is through up-regulation of E12/E47 bHLH proteins that may in turn up-regulate p21 [60] expression at transcriptional level. 


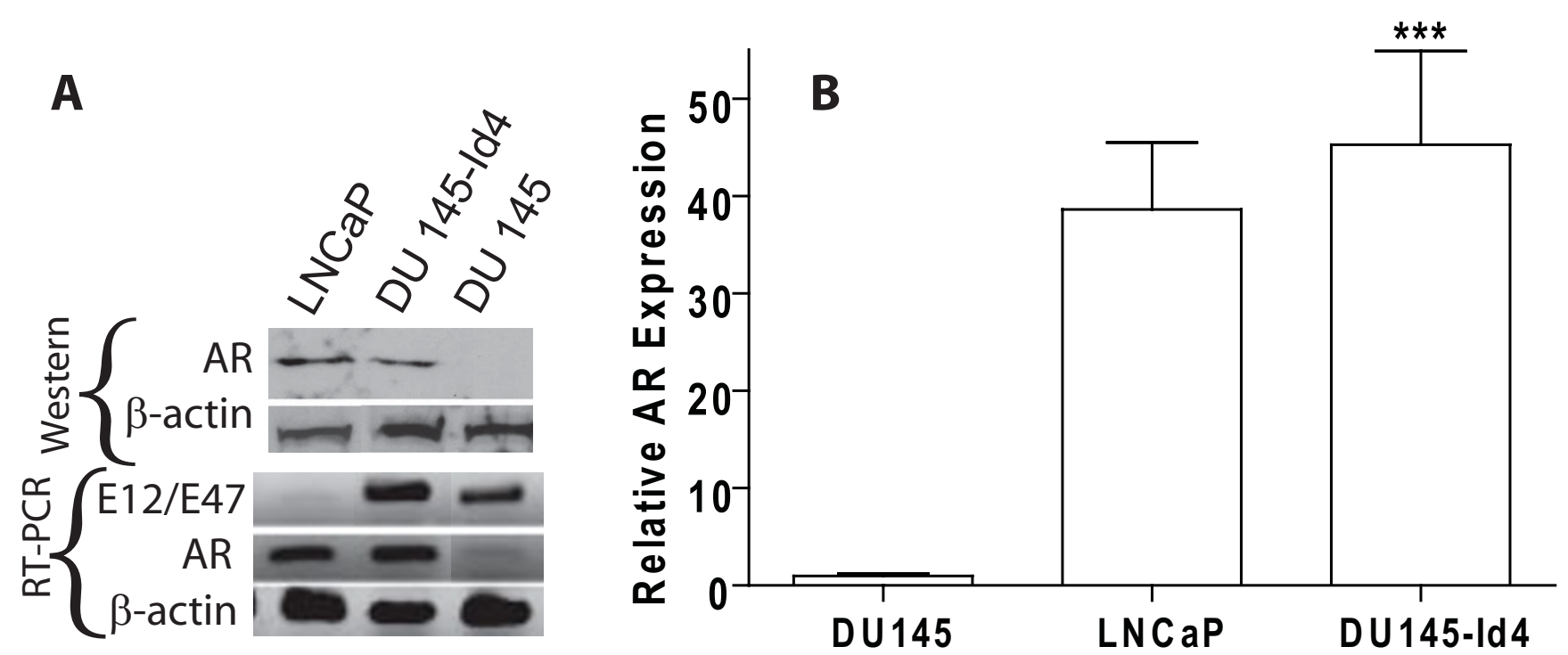

Figure 7

(A): Western blot analysis of Androgen receptor expression analysis (Upper Panel). Lower Panel: Expression of androgen receptor (AR) and E2A (EI2/E47) bHLH transcription factor by RT-PCR. The gain of androgen receptor expression in DUI45-Id4 cells as compared to DUI45 cells at the transcript and protein level is evident. The total RNA and protein was purified from DUI45-Id4 at passage 28 and analyzed for the expression studies. As controls, the parental, mock transfected DUI45 cells (AR -ve) and LNCaP (AR +ve) cell lines were used. The expression of beta-actin was used as loading and RT-PCR control. The data is representative of at least three different RT-PCR reactions and Western blot analysis. The following primers were used: E2A F-5' CAC CAG CCC TCA TGC ACA ACC, R-5' CTC CAA CCA CAC CTG ACA C and androgen receptor (AR): F-5' ATG GTG AGC AGA GTG CCC TA and R-5' GTG GTG CTG GAA GCC TCT CCT. (B) Real time PCR analysis, performed on the same batch of reverse transcribed RNA used in panel A confirms the RT-PCR data. The fold change in AR expression is normalized to beta-actin (3 different RT reactions) and calculated by the $\Delta \mathrm{Ct}$ method as described in materials and methods section $(* * * \mathrm{P}<0.001)$.

Collectively, our results suggest that Id 4 acts as a potential tumor suppressor, possibly through multiple pathways. The underlying molecular mechanisms are likely to be complex that may involve gene specific Id 4 targets or more global, involving changes in response to trophic factors and modulation of overall transcriptional machinery.

\section{Discussion}

In this report we demonstrate that $\mathrm{Id} 4$ acts as a putative tumor suppressor. The tumor suppressor role of Id4 appears to be unique as compared to other members of the Id gene family (Id1, Id2 and Id3) that may act as oncogenes or co-operating oncogenes in many cancers $[24,27,30]$.

Hypermethylation of $\mathrm{CpG}$ islands near gene promoter regions is associated with transcriptional inactivation and represents an important mechanism of gene silencing in carcinogenesis [61,62]. Epigenetic silencing (promoter hyper-methylation) of Id4 in cancers from different organs such as in T-/natural killer acute lymphoblastic leukemia [33], gastric [37], breast [35] and colorectal cancers [36] suggests its role as a putative tumor suppressor. Analysis of public microarray databases provides strong evidence that Id 4 is down regulated in prostate cancer also [51-54]. At the mechanistic level, the transcriptional inactivation of Id4 is associated with aberrant promoter methylation in a model prostate cancer cell line DU145.

At the molecular level, its core function as a dominant negative regulator of bHLH activity is conserved with its other three family members (Id1, Id2 and Id3). Id4 efficiently dimerizes with $\mathrm{E}$ proteins and blocks trans-activation of $\mathrm{E}$ box dependent genes [63]. Beyond this conserved role, the non-bHLH interaction partners that define global or cell type specific Id4 functions are largely unknown. For example, interactions of Id2 with $\mathrm{Rb}[8,9]$ and polycystins [10], Id1 and Id3 with Ets [13] transcription factors largely contribute to their oncogenic potential by releasing cell cycle blockade at multiple levels [32].

The effect of Id4 leading to decreased proliferation and Sphase arrest in DU145 prostate cancer cell line may be due to increase in the expression of tumor suppressors E-cadherin, p27, p21 and the bHLH transcription factors E12/ E47 [64-67] and/or activation of previously silenced tumor suppressors. The increase in the transcript of $\mathrm{p} 27$ and p 21 suggests that Id 4 over-expression modifies intra- 

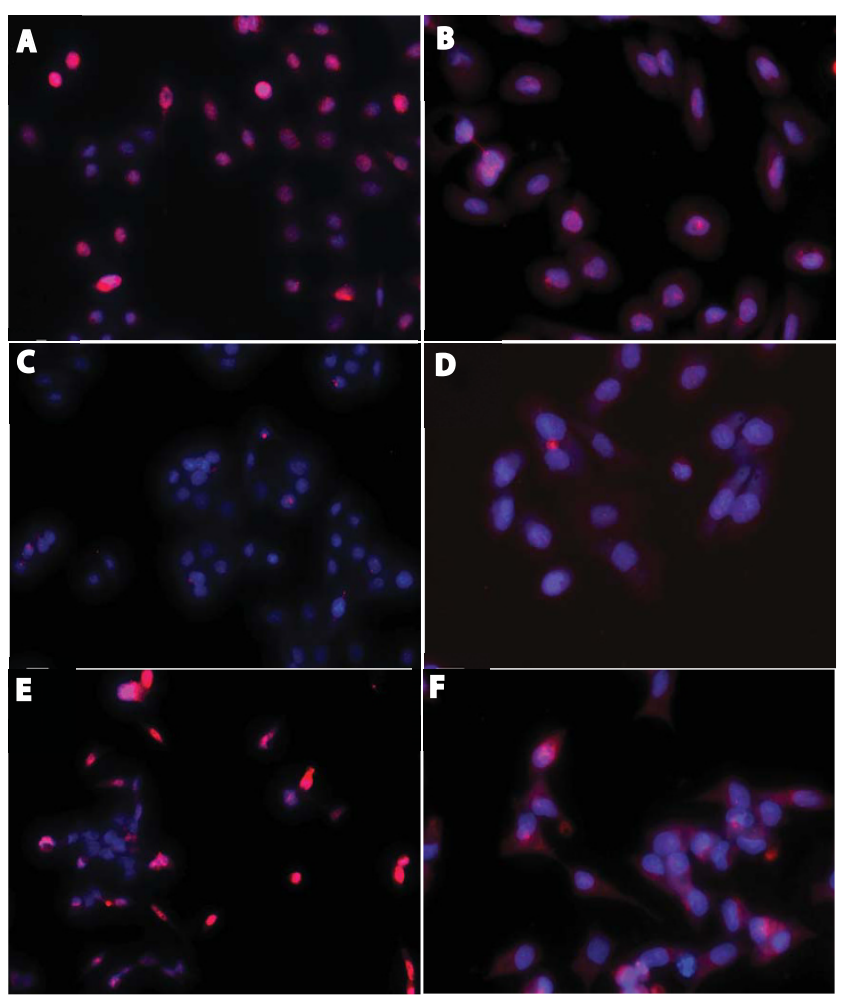

Figure 8

Fluorescence immuno-cytochemistry demonstrating expression and localization of androgen receptor (AR) at the cellular level. The cells were processed for immuno-cytochemistry as described in the materials and methods section. The red fluorescence demonstrates $A R$ (panels A, C, E) or $\beta$-actin (panels B, D, F). The cells were counterstained with DAPI (blue) to reveal the nucleus. The red (antigen specific) and blue (nucleus) images were superimposed to demonstrate cellular localization of the antigen (AR or $\beta$-actin). Androgen receptor expression was localized primarily to the nucleus in LNCaP (panel E, AR+ve control) and DUI45-Id4 (Panel A). In contrast, $\beta$-actin expression was primarily cytoplasmic (panels $B, D, F$ ). The AR expression in parental DUI 45 cells was not observed (panel C). Panels A and B: DUI45-Id4, Panels C and D: DUI45 and Panels E and F: LNCaP. The anti-AR and anti- $\beta$ actin antibodies were highly specific and displayed no non-specific binding as determined by western blot analysis (e.g. Fig 7A). The photomicrographs $(\times 200)$ are representative of at least 3 different experiments performed in replicates.

cellular transcriptional pathways leading to increased p27 and p21 expression itself. The increase in E-cadherin could be due to neutralization of bHLH transcriptional inhibitors [68] by Id4 or a secondary event elicited by increased p27 expression [69].

The p21 levels could be partially responsible for the increased p53 expression [70] in DU145-Id4 cells. However, the S-phase arrest and apoptosis appears to be p53 dispensable since p53 is expressed in a mutant form (p53 $\mathrm{mt} / \mathrm{mt}$ ) in DU145 cells [71]. A similar S-phase arrest observed in PC3-Id4 cells that are null for p53 further supports this mechanism. The p53 mutations in DU145 cells are within the DNA binding domain (P223L and V274F) that abrogates its transcriptional activity. The rate of apoptosis in DU145-Id4 expressing ectopic wild type p53 or alternate apoptotic pathways involving NFkB, Bcl-2, Bcl-xl needs to be investigated to further clarify mechanism of action of Id4 in apoptosis and S-phase arrest. The epigenetic silencing of p21 and p16 in PC3 cells as reported previously [72,73] but not in DU145 (this study) suggest that the molecular mechanisms involved in S-Phase and G2/M phase arrest in PC3 cells could be unique that remains to be investigated. Our data, however does confirm that Id4 is involved in blocking the cell cycle of prostate cancer cell lines DU145 and PC3. It is also speculated that the mechanism by which Id4 promotes S-phase arrest could be independent of CDKNIs and involve mechanisms that remains to be investigated.

Re-expression of functional AR can be achieved by treating the DU145 cells with non-selective de-methylating agents such as 5-aza-2' deoxycytidine $[55,74]$ or treatment with growth factor NGF [75]. However, low AR expression in spite of its promoter methylation reportedly exists in DU145 cells [56]. An increased AR expression could therefore involve restoration of a transcriptional network by Id4 in DU145 cells at the non-epigenetic (signaling, transcriptional) level. A similar mechanism could also be operational for p53 expression that involve Id4 directly, or indirectly through increased p21 expression [70].

Evidence also suggests that Id4 can act as promoter of neoplastic transformation/growth. In breast cancer cells, Id4 and BRCA1 are in a negative feedback loop $[15,16,76]$. In rat mammary gland carcinoma, Id4 expression is associated with proliferation and invasiveness [39]. In other studies, Id 4 was down regulated due to promoter hypermethylation in breast cancer $[34,35]$. Therefore, even in cancers arising from the same organ such as the breast, Id 4 may have opposing effects $[15,16,34,35,39,76]$. Id4 is also over-expressed in acute lymphoblastic leukemia due to a $\mathrm{t}(6 ; 14)(\mathrm{p} 22 ; \mathrm{q} 32$ translocation [40]. Thus, Id4 appears to exhibit unique regulatory functions in diverse cancer types. Collectively, these diverse and conflicting results points towards a complex function of Id 4 that is probably dependent on a particular genetic background.

A recent report suggested a positive association between Id4 expression and prostate cancer metastasis [77]. In this report, the authors used an anti-Id4 antibody that crossreacts with multiple proteins in Western blot analysis in our laboratory. On the contrary, our analysis of five independent prostate cancer microarray databases strongly 
suggests that Id4 is down-regulated in prostate cancer. The development and use of a highly selective antibody will thus ensure the quality and consistency of the data that will significantly advance our understanding of Id4 protein expression in cancers.

\section{Conclusion}

The data strongly supports the role of $\mathrm{Id} 4$ as a putative tumor suppressor that may act as a regulatory gene by redirecting cell growth and differentiation. Nevertheless, the opposing functions of Id4 in cancer cells suggest that its molecular mechanism of action may depend on the genotype that may be permissive for its pro- or anti-neoplastic function. This permissive genotype or a "switch" will essentially be determined by the presence/absence of specific Id 4 interactions partners or signaling mechanisms that modify response to trophic factors.

It is necessary to analyze Id4 methylation status and expression levels in primary tumor samples as well as in normal prostate tissues in order to further clarify the role of epigenetic silencing of Id 4 in prostate cancer. Since epigenetic aberrations are pharmacologically reversible, DNA methylation changes have become attractive targets for cancer treatment with de-methylating agents, leading to reactivation of silenced genes. The identification of novel target genes that may undergo epigenetic silencing in prostate cancer will be important for the development of future therapeutic and diagnostic strategies for clinical application.

\section{Competing interests}

The authors declare that they have no competing interests.

\section{Authors' contributions}

JPWC and AJA contributed equally to the manuscript. AJA developed the DU145-Id4 cell line and JPWC performed subsequent analysis. OG performed methylation analysis of the Id 4 promoter. TAG performed androgen receptor western blot and immuno-cytochemistry. JC participated in the study design, reviewed all data and prepared the manuscript. All authors read and approved the final manuscript.

\section{Acknowledgements}

Part of this work were supported by NIH/NCRR/RCMI Grant \# GI2RR03062 at CAU to JC. Initial funding for this work was from the Center for Reproductive Biology, Washington State University, Pullman, WA 99164 to JC. The authors wish to thank Ms. Michelle Schmidt for her technical support.

\section{References}

I. Massari ME, Murre C: Helix-loop-helix proteins: regulators of transcription in eucaryotic organisms. Mol Cell Biol 2000, 20(2):429-440.
2. Benezra R, Davis RL, Lockshon D, Turner DL, Weintraub H: The protein Id: a negative regulator of helix-loop-helix DNA binding proteins. Cell I990, 6 I (I):49-59.

3. Murre C, Bain G, van Dijk MA, Engel I, Furnari BA, Massari ME, Matthews JR, Quong MW, Rivera RR, Stuiver MH: Structure and function of helix-loop-helix proteins. Biochim Biophys Acta 1994, I 2 | 8(2): | 29-| 35.

4. Murre C, McCaw PS, Baltimore D: A new DNA binding and dimerization motif in immunoglobulin enhancer binding, daughterless, MyoD, and myc proteins. Cell 1989, 56(5):777-783.

5. Cooper CL, Newburger PE: Differential expression of Id genes in multipotent myeloid progenitor cells: Id-I is induced by early-and late-acting cytokines while Id-2 is selectively induced by cytokines that drive terminal granulocytic differentiation. J Cell Biochem 1998, 7 I (2):277-285.

6. Jen $Y$, Manova K, Benezra R: Each member of the Id gene family exhibits a unique expression pattern in mouse gastrulation and neurogenesis. Dev Dyn 1997, 208(I):92-106.

7. Riechmann V, van Cruchten I, Sablitzky F: The expression pattern of Id4, a novel dominant negative helix-loop-helix protein, is distinct from IdI, Id2 and Id3. Nucleic Acids Res 1994, 22(5):749-755.

8. lavarone A, Garg P, Lasorella A, Hsu J, Israel MA: The helix-loophelix protein Id-2 enhances cell proliferation and binds to the retinoblastoma protein. Genes Dev 1994, 8(I I): I270-I 284.

9. Lasorella $A$, lavarone $A$, Israel MA: Id2 specifically alters regulation of the cell cycle by tumor suppressor proteins. Mol Cell Biol 1996, 16(6):2570-2578.

10. Li X, Luo Y, Starremans PG, McNamara CA, Pei Y, Zhou J: Polycystin-I and polycystin-2 regulate the cell cycle through the helix-loop-helix inhibitor Id2. Nat Cell Biol 2005, 7(12): $1202-1212$.

II. Samanta J, Kessler JA: Interactions between ID and OLIG proteins mediate the inhibitory effects of BMP4 on oligodendroglial differentiation. Development 2004, I 3 | ( I 7):4|3|-4|42.

12. Qi J, Su Y, Sun R, Zhang F, Luo X, Yang Z, Luo X: CASK inhibits ECV 304 cell growth and interacts with Id I. Biochem Biophys Res Commun 2005, 328(2):517-52I.

13. Xiao X, Athanasiou M, Sidorov IA, Horikawa I, Cremona G, Blair D, Barret JC, Dimitrov DS: Role of Ets/ld proteins for telomerase regulation in human cancer cells. Exp Mol Pathol 2003, 75(3):238-247.

14. Roberts EC, Deed RW, Inoue T, Norton JD, Sharrocks AD: Id helixloop-helix proteins antagonize pax transcription factor activity by inhibiting DNA binding. Mol Cell Biol 200 I, 2 I (2):524-533.

15. Beger C, Pierce LN, Kruger M, Marcusson EG, Robbins JM, Welcsh P, Welch PJ, Welte K, King MC, Barber JR, et al.: Identification of Id4 as a regulator of BRCAI expression by using a ribozymelibrary-based inverse genomics approach. Proc Natl Acad Sci USA 200I, 98(I): I30-135.

16. Welcsh PL, Lee MK, Gonzalez-Hernandez RM, Black DJ, Mahadevappa M, Swisher EM, Warrington JA, King MC: BRCAI transcriptionally regulates genes involved in breast tumorigenesis. Proc Natl Acad Sci USA 2002, 99(I I):7560-7565.

17. Hasskarl J, Duensing S, Manuel E, Munger K: The helix-loop-helix protein IDI localizes to centrosomes and rapidly induces abnormal centrosome numbers. Oncogene 2004, 23(10): 1930-1938.

18. Florio M, Hernandez MC, Yang H, Shu HK, Cleveland JL, Israel MA: Id2 promotes apoptosis by a novel mechanism independent of dimerization to basic helix-loop-helix factors. Mol Cell Biol 1998, 18(9):5435-5444.

19. Gleichmann M, Buchheim G, El-Bizri H, Yokota Y, Klockgether T, Kugler S, Bahr M, Weller M, Schulz JB: Identification of inhibitorof-differentiation 2 (Id2) as a modulator of neuronal apoptosis. I Neurochem 2002, 80(5):755-762.

20. Barone MV, Pepperkok R, Peverali FA, Philipson L: Id proteins control growth induction in mammalian cells. Proc Natl Acad Sci USA 1994, 9 I ( I I):4985-4988.

21. Hara E, Yamaguchi T, Nojima H, Ide T, Campisi J, Okayama H, Oda $\mathrm{K}$ : Id-related genes encoding helix-loop-helix proteins are required for $\mathbf{G I}$ progression and are repressed in senescent human fibroblasts. J Biol Chem 1994, 269(3):2139-2I 45. 
22. Norton JD, Deed RW, Craggs G, Sablitzky F: Id helix-loop-helix proteins in cell growth and differentiation. Trends Cell Biol 1998 , 8(2):58-65.

23. Coppe JP, Smith AP, Desprez PY: Id proteins in epithelial cells. Exp Cell Res 2003, 285(I): |3|-|45.

24. Hasskarl J, Munger K: Id proteins - tumor markers or oncogenes? Cancer Biol Ther 2002, I(2):91-96.

25. Israel MA, Hernandez MC, Florio M, Andres-Barquin PJ, Mantani A, Carter JH, Julin CM: Id gene expression as a key mediator of tumor cell biology. Cancer Res 1999, 59(7 Suppl): I726s-1730s.

26. Lasorella $A$, Uo $T$, lavarone $A$ : Id proteins at the cross-road of development and cancer. Oncogene 200I, 20(58):8326-8333.

27. Norton JD: ID helix-loop-helix proteins in cell growth, differentiation and tumorigenesis. I Cell Sci 2000, IIJ3(Pt 22):3897-3905.

28. Perk J, lavarone A, Benezra R: Id family of helix-loop-helix proteins in cancer. Nat Rev Cancer 2005, 5(8):603-6I4.

29. Ruzinova MB, Benezra R: Id proteins in development, cell cycle and cancer. Trends Cell Biol 2003, I3(8):410-4I8.

30. Wong YC, Wang X, Ling MT: Id-I expression and cell survival. Apoptosis 2004, 9(3):279-289.

31. Yokota Y, Mori S: Role of Id family proteins in growth control. J Cell Physiol 2002, I 90(I):2I-28.

32. Zebedee Z, Hara E: Id proteins in cell cycle control and cellular senescence. Oncogene 200I, 20(58):8317-8325.

33. Yu L, Liu C, Vandeusen J, Becknell B, Dai Z, Wu YZ, Raval A, Liu TH, Ding W, Mao C, et al.: Global assessment of promoter methylation in a mouse model of cancer identifies ID4 as a putative tumor-suppressor gene in human leukemia. Nat Genet 2005, 37(3):265-274.

34. Umetani N, Mori T, Koyanagi K, Shinozaki M, Kim J, Giuliano AE Hoon DS: Aberrant hypermethylation of ID4 gene promoter region increases risk of lymph node metastasis in $\mathrm{TI}$ breast cancer. Oncogene 2005, 24(29):472I-4727.

35. Noetzel E, Veeck J, Niederacher D, Galm O, Horn F, Hartmann A, Knuchel R, Dahl E: Promoter methylation-associated loss of ID4 expression is a marker of tumour recurrence in human breast cancer. BMC Cancer 2008, 8: 154.

36. Umetani N, Takeuchi H, Fujimoto A, Shinozaki M, Bilchik AJ, Hoon DS: Epigenetic inactivation of ID4 in colorectal carcinomas correlates with poor differentiation and unfavorable prognosis. Clin Cancer Res 2004, I 0(22):7475-7483.

37. Chan AS, Tsui WY, Chen X, Chu KM, Chan TL, Li R, So S, Yuen ST, Leung SY: Downregulation of ID4 by promoter hypermethylation in gastric adenocarcinoma. Oncogene 2003 22(44):6946-6953.

38. Wu Q, Hoffmann MJ, Hartmann FH, Schulz WA: Amplification and overexpression of the ID4 gene at 6p22.3 in bladder cancer. Mol Cancer 2005, 4(I): I6.

39. Shan L, Yu M, Qiu C, Snyderwine EG: Id4 regulates mammary epithelial cell growth and differentiation and is overexpressed in rat mammary gland carcinomas. Am J Pathol 2003, I 63(6):2495-2502.

40. Bellido M, Aventin A, Lasa A, Estivill C, Carnicer MJ, Pons C, MatiasGuiu X, Bordes R, Baiget M, Sierra J, et al.: Id4 is deregulated by a $\mathbf{t}(6 ; 14)(\mathbf{p 2 2} ; \mathbf{q 3 2})$ chromosomal translocation in a B-cell lineage acute lymphoblastic leukemia. Haematologica 2003, 88(9):994-1001.

41. Russell L], Akasaka T, Majid A, Sugimoto KJ, Loraine Karran E, Nage I, Harder L, Claviez A, Gesk S, Moorman AV, et al.: t(6; 14)(p22;q32): a new recurrent IGH@ translocation involving ID4 in B-cell precursor acute lymphoblastic leukemia (BCP-ALL). Blood 2008, I I I (I):387-39I.

42. Chaudhary J, Schmidt M, Sadler-Riggleman I: Negative acting HLH proteins Id I, Id 2, Id 3, and Id 4 are expressed in prostate epithelial cells. Prostate 2005, 64(3):253-264.

43. Asirvatham Al, Schmidt MA, Chaudhary J: Non-redundant inhibitor of differentiation (Id) gene expression and function in human prostate epithelial cells. Prostate 2006, 66(9):921-935.

44. Myers MA: Direct measurement of cell numbers in microtitre plate cultures using the fluorescent dye SYBR green I. J Immunol Methods 1998, 2 I 2(I):99-103.

45. Hang $\mathrm{H}$, Fox $\mathrm{MH}$ : Analysis of the mammalian cell cycle by flow cytometry. Methods Mol Biol 2004, 241:23-35.

46. Ramachandran S, Liu P, Young AN, Yin-Goen Q, Lim SD, Laycock N, Amin MB, Carney JK, Marshall FF, Petros JA, et al.: Loss of HOXC6 expression induces apoptosis in prostate cancer cells. Oncogene 2005, 24(I): 188-198.

47. Sailer BL, Valdez JG, Steinkamp JA, Crissman HA: Apoptosis induced with different cycle-perturbing agents produces differential changes in the fluorescence lifetime of DNA-bound ethidium bromide. Cytometry 1998, 3 I(3):208-216

48. Herman JG, Graff JR, Myohanen S, Nelkin BD, Baylin SB: Methylation-specific PCR: a novel PCR assay for methylation status of CpG islands. Proc Natl Acad Sci USA 1996, 93( I 8):982 I-9826.

49. Galm O, Herman JG: Methylation-specific polymerase chain reaction. Methods Mol Med 2005, I I 3:279-29I.

50. Rhodes DR, Yu J, Shanker K, Deshpande N, Varambally R, Ghosh D Barrette T, Pandey A, Chinnaiyan AM: ONCOMINE: a cancer microarray database and integrated data-mining platform. Neoplasia 2004, 6(I): I-6.

5I. Lapointe J, Li C, Higgins JP, Rijn M van de, Bair E, Montgomery K, Ferrari M, Egevad L, Rayford W, Bergerheim U, et al.: Gene expression profiling identifies clinically relevant subtypes of prostate cancer. Proc Natl Acad Sci USA 2004, I 0 I (3):8I I-8I 6.

52. Varambally S, Yu J, Laxman B, Rhodes DR, Mehra R, Tomlins SA, Shah RB, Chandran U, Monzon FA, Becich MJ, et al.: Integrative genomic and proteomic analysis of prostate cancer reveals signatures of metastatic progression. Cancer Cell 2005, 8(5):393-406.

53. Dhanasekaran SM, Dash A, Yu J, Maine IP, Laxman B, Tomlins SA, Creighton C], Menon A, Rubin MA, Chinnaiyan AM: Molecular profiling of human prostate tissues: insights into gene expression patterns of prostate development during puberty. Faseb J 2005, I 9(2):243-245.

54. Tomlins SA, Mehra R, Rhodes DR, Cao X, Wang L, Dhanasekaran SM, Kalyana-Sundaram S, Wei JT, Rubin MA, Pienta KJ, et al.: Integrative molecular concept modeling of prostate cancer progression. Nat Genet 2007, 39(I):4I-5I.

55. Jarrard DF, Kinoshita H, Shi Y, Sandefur C, Hoff D, Meisner LF, Chang C, Herman JG, Isaacs WB, Nassif N: Methylation of the androgen receptor promoter CpG island is associated with loss of androgen receptor expression in prostate cancer cells. Cancer Res 1998, 58(23):5310-53|4.

56. Alimirah F, Chen J, Basrawala Z, Xin H, Choubey D: DU-I45 and PC-3 human prostate cancer cell lines express androgen receptor: implications for the androgen receptor functions and regulation. FEBS Lett 2006, 580(9):2294-2300.

57. Sun XH, Copeland NG, Jenkins NA, Baltimore D: Id proteins Id I and Id2 selectively inhibit DNA binding by one class of helixloop-helix proteins. Mol Cell Biol I99I, I I (I I):5603-56 I I

58. Goldfarb AN, Flores JP, Lewandowska K: Involvement of the E2A basic helix-loop-helix protein in immunoglobulin heavy chain class switching. Mol Immunol 1996, 33(I I-I 2):947-956.

59. Voronova AF, Lee F: The E2A and tal-I helix-loop-helix proteins associate in vivo and are modulated by Id proteins during interleukin 6-induced myeloid differentiation. Proc Nat Acad Sci USA 1994, 9 I ( I 3):5952-5956.

60. Prabhu S, Ignatova A, Park ST, Sun XH: Regulation of the expression of cyclin-dependent kinase inhibitor p2I by E2A and Id proteins. Mol Cell Biol 1997, I 7( I 0):5888-5896.

61. Egger G, Liang G, Aparicio A, Jones PA: Epigenetics in human disease and prospects for epigenetic therapy. Nature 2004 429(6990):457-463.

62. Herman JG, Baylin SB: Gene silencing in cancer in association with promoter hypermethylation. N Engl J Med 2003, 349(2I):2042-2054.

63. Pagliuca A, Bartoli PC, Saccone S, Della Valle G, Lania L: Molecular cloning of ID4, a novel dominant negative helix-loop-helix human gene on chromosome 6p21.3-p22. Genomics 1995, 27(I):200-203.

64. Viglietto G, Motti ML, Fusco A: Understanding p27(kip I) deregulation in cancer: down-regulation or mislocalization. Cell Cycle 2002, I (6):394-400.

65. Bringold $F$, Serrano $M$ : Tumor suppressors and oncogenes in cellular senescence. Exp Gerontol 2000, 35(3):317-329.

66. Christofori G, Semb H: The role of the cell-adhesion molecule E-cadherin as a tumour-suppressor gene. Trends Biochem Sci 1999, 24(2):73-76.

67. Hay ED: An overview of epithelio-mesenchymal transformation. Acta Anat (Basel) 1995, I 54(I):8-20.

68. Perez-Moreno MA, Locascio A, Rodrigo I, Dhondt G, Portillo $F$ Nieto MA, Cano A: A new role for EI2/E47 in the repression of 
E-cadherin expression and epithelial-mesenchymal transitions. J Biol Chem 200I, 276(29):27424-2743I.

69. Supriatno, Harada K, Kawaguchi S, Yoshida H, Sato M: Effect of p27Kip I on the ability of invasion and metastasis of an oral cancer cell line. Oncol Rep 2003, I0(3):527-532.

70. Lavin MF, Gueven N: The complexity of p53 stabilization and activation. Cell Death Differ 2006, I3(6):941-950.

71. Isaacs WB, Carter BS, Ewing CM: Wild-type p53 suppresses growth of human prostate cancer cells containing mutant p53 alleles. Cancer Res I99I, 5 I ( 17):47I6-4720.

72. Bott SR, Arya M, Kirby RS, Williamson M: p2IWAFI/CIPI gene is inactivated in metastatic prostatic cancer cell lines by promoter methylation. Prostate Cancer Prostatic Dis 2005, 8(4):32I-326.

73. Jarrard DF, Bova GS, Ewing CM, Pin SS, Nguyen SH, Baylin SB, Cairns P, Sidransky D, Herman JG, Isaacs WB: Deletional, mutational, and methylation analyses of CDKN2 (p /6/MTSI) in primary and metastatic prostate cancer. Genes Chromosomes Cancer 1997, 19(2):90-96.

74. Nakayama T, Watanabe M, Suzuki H, Toyota M, Sekita N, Hirokawa Y, Mizokami A, Ito $H$, Yatani R, Shiraishi T: Epigenetic regulation of androgen receptor gene expression in human prostate cancers. Lab Invest 2000, 80( ( 2): $1789-1796$.

75. Sigala S, Tognazzi N, Rizzetti MC, Faraoni I, Missale C, Bonmassar E, Spano $P$ : Nerve growth factor induces the re-expression of functional androgen receptors and p75(NGFR) in the androgen-insensitive prostate cancer cell line DUI 45. Eur J Endocrinol 2002, 147(3):407-4I5.

76. Roldan G, Delgado L, Muse IM: Tumoral Expression of BRCAI, Estrogen Receptor Alpha and ID4 Protein in Patients with Sporadic Breast Cancer. Cancer Biol Ther 2006, 5(5):505-5I0.

77. Yuen HF, Chua CW, Chan YP, Wong YC, Wang X, Chan KW: Id proteins expression in prostate cancer: high-level expression of Id-4 in primary prostate cancer is associated with development of metastases. Mod Pathol 2006, 19(7):93I-94I.

\section{Pre-publication history}

The pre-publication history for this paper can be accessed here:

http://www.biomedcentral.com/1471-2407/9/173/pre pub
Publish with Biomed Central and every scientist can read your work free of charge

"BioMed Central will be the most significant development for disseminating the results of biomedical research in our lifetime. "

Sir Paul Nurse, Cancer Research UK

Your research papers will be:

- available free of charge to the entire biomedical community

- peer reviewed and published immediately upon acceptance

- cited in PubMed and archived on PubMed Central

- yours - you keep the copyright
BioMedcentral 